\title{
APPLYING MARKETING CONCEPTS IN CHEESEMAKING BUSINESS ENTITIES IN THE REPUBLIC OF SERBIA
}

\author{
Vuk Radojević , Dubravka Užar², Izabela Mugoša ${ }^{3}$ \\ *Corresponding authorE-mail: dubravka.uzar@gmail.com
}

\begin{abstract}
A R T I C LE IN F O
A B S T R A C T

Original Article

Main objective of the research is to identify role and

Received: 24 March 2020

Accepted: 16 May 2020

position of marketing in business practice in micro, small and medium-sized enterprises (MSME) in the Republic of Serbia. Since cheese is a value-added product, doi:10.5937/ekoPolj2003895R

UDC 658.8:339(497.11) cheesemaking takes a significant position in country's food chain and represents a significant revenue generator for every participant in the production cycle. Lack or

Keywords:

marketing, MSME in the Republic of Serbia, valueadded, cheese

JEL: M31, Q13 insufficient usage of marketing decreases the possibilities of efficient and effective use of resources and minimizes cheesemakers' competitive advantage. The research has been conducted in the form of a questionnaire by using a random sample of 39 business entities in the territory of the Republic of Serbia. Research results indicate that marketing is at a peripheral position in the business practice of the analysed business entities. Main precondition for marketing concept implementation is introduction of marketing function and formalized process of marketing planning integrated into corporate planning system and supported by each level of management structure.
\end{abstract}

(C) 2020 EA. All rights reserved.

\section{Introduction}

Global cheese consumption is increasing. Positive publicity, presence and market penetration of big cheesemakers into new markets, availability and wide range of cheese assortments, development of fast food industry, frozen food products, etc. affected the changes in consumers' eating habits and therefore the general increase in cheese demand. On the other hand, production and placement of cheese made in

1 Vuk Radojević, Ph.D., Assistant Professor, University of Novi Sad, Faculty of Agriculture, Trg Dositeja Obradovića 8, 21000 Novi Sad, Serbia, Phone: +381 214853 420, E-mail: radojevic.vuk@polj.uns.ac.rs, ORCID ID (http://orcid.org/0000-0002-3453-5236)

2 Dubravka Užar, MsC, Teaching Assistant, University of Novi Sad, Faculty of Agriculture, Trg Dositeja Obradovića 8, 21000 Novi Sad, Serbia, Phone: +381 214853 420, E-mail: dubravka.uzar@polj.uns.ac.rs, ORCID ID (http://orcid.org/0000-0002-0593-7383)

3 Izabela Mugoša, Ph.D., Development fund of the Autonomous Province of Vojvodina, Bulevar Cara Lazara 7a, Novi Sad, Serbia, Phone:+38121454334, E-mail: izabelamugosa@ gmail.com, ORCID ID (https://orcid.org/0000-0001-8811-5846)

http://ea.bg.ac.rs 
the Republic of Serbia is faced with changing opportunities and numerous challenges both in domestic and international market. Expected abolition of restrictions on dairy production in the EU as well as disrupted economic relations between the European Union and Russia resulted in higher delivery of dairy products at a lower price into the market of neighbouring countries. Placement of cheese produced in the Republic of Serbia was additionally aggravated because of Croatia had left CEFTA in 2013 and presence of wide range of different top cheese manufacturers' products in member countries' markets. Degree of marketing implementation in business practice is one of key factors of modern market operations that differentiate the offer and determine the level of competitiveness and profitability. Strategic choices, in the form of intentions, occur before strategy implementation in both individual and collective conscious of company decision-makers (Gagné, 2018). Defining objectives, the possibilities of attaining those objectives, market performance and growth dynamics of cheesemaking business entities largely depends on the decision-makers and executors' perception of marketing role and significance.

Micro, small and medium-sized enterprises (MSME) represent the most efficient segment of economy in nearly every country. These enterprises are becoming competitive with large enterprises, successfully participating in global economy trends, applying new and innovation technologies (Ožegović, et al., 2012). Despite still being chiefly focused on the local market, small and medium-sized enterprises have an increasingly important role in the international exchange too (Pavlović, 2009). These companies generate the largest contribution to increasing employment, gross value added and trade thus being considered as the frame for national economic growth and development (Erić et al., 2012).

Demand is the main factor that affects changes in production. It is affected by demographic characteristics, world population growth, changes in consumers' eating habits and increased cheese consumption on daily basis. Other factors that also affect adjustment of the offer are introduction and development of new products intended for target groups such as vegetarians, luxury consumers, teenagers as well as consumers with specific health issues. Level of marketing concept comprehension, including perception and implementation of the most efficient marketing mix elements for catering to needs and wishes of target consumers determines the capacity of business entities to deliver value. Higher level of delivered value in comparison to competition will affect the increase of market share as the final outcome as well as growth rate of cheese placement in terms of value and quantity and, eventually, the total growth and development of cheesemakers in the Republic of Serbia. A fundamental characteristic of agriculture in all countries in the world is the domestic production to ensure their needs and then to surpluses for export; objective which can only be achieved by allocating additional funds for investment required for development and modernization process of permanent production agriculture (Cicea, et al., 2010), with marketing included as its constitutional part. 
In order to create and maintain competitive advantage, in the request of many market challenges such as the presence of numerous foreign brands and local cheeses, low purchasing power of buyers, insufficient quantities of milk from domestic production, high standards regarding food safety, requirements and propositions of distributors and retailers, limited financial resources, etc., strategic marketing planning and use of instruments marketing become imperative on the road to market affirmation and increasing market share (Mugoša, 2018). The paper aims to identify the role of marketing and its position in business practice in micro, small and medium-sized enterprises (MSME) in the Republic of Serbia. Perceiving business entities' marketing implementation and methods they put marketing mix instruments to use leads to a better understanding of framework of interventions needed to strengthen their business competence and competitiveness.

\section{Material and methods}

Survey research by use of a questionnaire was conducted for the purposes of obtaining empirical data. Veterinary Directorate of the Republic of Serbia provided the data on legal and business entities; micro, small and medium-sized enterprises. Geographic segmentation of available data was used to identify business entities according to their administrative divisions. A great number of business entities from the records (nearly 260 recorded legal and business entities) went out of business in the meantime. Therefore, it was necessary to turn to Veterinary Directorate's district units for assistance in order to determine currently active cheesemakers. Hence, 24 out of 29 district units have been contacted, while the research was carried out in 19 administrative districts of the Republic of Serbia. Altogether 39 legal entities from 19 administrative districts of the Republic of Serbia participated in the survey. The greatest proportion of interviewed business entities belongs to three administrative districts: 8 respondents in Zlatibor District (20.5\%), 6 respondents in South Banat District (15.4\%) and 3 in Pirot District (7.7\%) who take up $43.6 \%$ of the total number of respondents. Foundation dates of the respondents' business entities indicate that medium-sized enterprises have been in business for the longest period of time (18.6 years on average) followed by small enterprises with 15.4 years and micro enterprises being in business for the shortest amount of time which is 11 years on average.

An overview of educational background indicates significant participation of university degree marketing decision-makers. The most significant internal factors affecting company marketing strategy are the following: availability of funds, managerial skills, level of education and expertise, personal skills and entrepreneurial inclination (Lakhanya, 2015) as well as marketing and sales experts which has been noticed particularly in micro enterprises (Jones, et al., 2013). Average age of marketing decisionmakers is 46.2. The oldest decision-makers are located in medium-sized enterprises with an average age of 47.3 followed by slightly lower average age of decision-makers in small (46.7) and micro enterprises (45.3). In the respondent structure, micro legal entities with 18 respondents take up $46.4 \%$, small legal entities take up $38.5 \%$ which is 
equivalent to 15 respondents and finally 6 respondents from medium-sized legal entities belong to the remaining $15.4 \%$. Average volume of annual cheese production of micro enterprises is 94.3 tonnes followed by 207.44 tonnes made by the small enterprises and 727.6 tonnes coming from the medium-sized enterprises.

Annual budget for investment in marketing does not exceed 500 EUR (equivalent to Serbian dinars) in case of one-third of manufacturers who responded to this question, whereas 73.3\% manufacturers spend no more than 2000 EUR for marketing purposes (table 1). Widespread opinion among owners and managers is that marketing represents a cost, which is correct if there is no vision, no mission statement and that company goals, i.e. marketing objectives and strategies are vaguely expressed or completely absent. Although it generates costs which are necessary in order to perform different marketing activities, marketing represents an investment which impacts product value and positively affects sales even after the costs of certain marketing activities have occurred.

Table 1. Degree of marketing investments in micro, small and medium-sized enterprises in relation to production volume

\begin{tabular}{|c|c|c|c|c|c|}
\hline $\begin{array}{l}\begin{array}{l}\text { Degree of marketing } \\
\text { investment, EUR }\end{array} \\
\text { Production } \\
\text { volume }\end{array}$ & $\begin{array}{c}\text { Up } \\
\text { to } 99 \\
\text { tonnes }\end{array}$ & $\begin{array}{c}100-299 \\
\text { tonnes }\end{array}$ & $\begin{array}{c}300-299 \\
\text { tonnes }\end{array}$ & $\begin{array}{l}600 \text { tonnes } \\
\text { and above }\end{array}$ & Total \\
\hline & \multicolumn{5}{|c|}{$(\%)$} \\
\hline 0 & 5.9 & 0.0 & 0.0 & 0.0 & 3.3 \\
\hline $1-500$ & 35.3 & 22.2 & 0.0 & 0.0 & 26.7 \\
\hline $501-1,000$ & 29.4 & 22.2 & 0.0 & 0.0 & 23.3 \\
\hline $1,001-2,000$ & 17.6 & 22.2 & 33.3 & 0.0 & 20.0 \\
\hline $2,001-5,000$ & 5.9 & 22.2 & 0.0 & 0.0 & 10.0 \\
\hline $5,001-10,000$ & 0.0 & 0.0 & 66.7 & 0.0 & 6.7 \\
\hline $10,001-15,000$ & 0.0 & 11.1 & 0.0 & 100.0 & 6.7 \\
\hline Above 15,000 & 5.9 & 0.0 & 0.0 & 0.0 & 3.3 \\
\hline Total number of responses & 100.0 & 100.0 & 100.0 & 100.0 & 100.0 \\
\hline
\end{tabular}

Source: Author's calculation based on the questionnaire data

Data indicates that cheesemakers in the Republic of Serbia are primarily oriented towards production and sales. Under conditions of modern market operations characteristic of numerous competition and cheese brands, cheesemakers cannot meet consumer needs and requirements as well as competitive advantage and market share increase without consistent marketing orientation. Besides jeopardizing growth and development of cheesemakers, absence of strategic and tactical marketing activities threatens their survival in the market. Office of Entrepreneurial Development of the United States of America recommends the so-called start-up for entrepreneurs who are starting a business and small enterprises in the amount of $2-3 \%$ of revenue for marketing budget to as much as $20 \%$ if the business belongs to a highly competitive industry. Most marketing experts agree on funding 1 to $10 \%$ of revenue necessary for marketing activities planning which depends on business's life span, competitive activity and company's financial capability. According to the research 
conducted in 2010, 58\% of 6,000 marketing managers responded that their companies invest less than $4 \%$ of annual revenue for marketing (www.smallbusiness.chron.com). Based on examined business entities' financial reports from 2014 and statements made by marketing decision-makers regarding the amount of funds annually invested for marketing purposes, it can be concluded that without regards to business size and life span cheesemakers invest an average of $0,003 \%$ of revenue from sales and services into marketing.

Type of the survey used is personal interview survey conducted via e-mail or telephone with manufacturers who agreed to participate in research. The questionnaire included 29 questions and it represents a combination of open-ended and closed-ended questions adjusted to each respondent's target group. Data on product range was collected by personal interview followed by internet presentation research as well as author's own research of cheese distribution channels. In processing the obtained data we used descriptive statistics and analytical statistic methods. Data interpretation and analysis as well as conclusions represent an information synthesis obtain based on the cheesemakers' attitudes, general statistics and other secondary sources, on the basis of which a SWOT analysis was performed, as a proposal of strategic option.

\section{Results and discussion}

In order to identify the role of marketing and its position in business practice in micro, small and medium-sized enterprises (MSMEs) in the Republic of Serbia, it is necessary to determine whether companies have a specific sector related to marketing. Regarding the question whether marketing department exists, $64.1 \%$ of total number of participants responded negatively claiming that all decisions are made by the owner, i.e. company manager. Marketing activities are performed within other (mostly commercial) departments in $33.3 \%$ of enterprises and only $2.6 \%$, i.e. one enterprise has a developed marketing department (Table 2).

Table 2. Marketing department presence in micro, small and medium-sized enterprises

\begin{tabular}{|c|c|c|c|c|c|}
\hline Does marketing department exist & - & Micro & Small & Medium & Total \\
\hline Yes. & $(\%)$ & 0.0 & 6.7 & 0.0 & 2.6 \\
\hline $\begin{array}{l}\text { No separate department, marketing is within } \\
\text { another department. }\end{array}$ & $(\%)$ & 11.1 & 46.7 & 66.7 & 33.3 \\
\hline $\begin{array}{l}\text { Doesn't exist, marketing related decisions are } \\
\text { made by the owner or manager. }\end{array}$ & $(\%)$ & 88.9 & 46.7 & 33.3 & 64.1 \\
\hline Total & $\%$ & 100.0 & 100.0 & 100.0 & 100.0 \\
\hline
\end{tabular}

Source: Author's calculation based on the questionnaire data

When it comes to micro enterprises $(88.9 \%)$, decisions are most frequently made by the owner. These decisions are informal, i.e. not a result of marketing planning. While business entities experience growth, information received from the commercial department contribute to marketing decision-making in $46.7 \%$ of small enterprises. 
Although it does not officially exist as a separate department, marketing is defined as a business activity within the commercial department in $66.7 \%$ of medium-sized enterprises. There is only one company classified as a medium-sized enterprise that uses other legal entities' external marketing and consulting services.

Strategic marketing planning starts from the defined business purpose, that is, clearly defined company mission statement which describes company scope of operations, its business goals, consumers, competences required to achieve those goals, etc, (McDonald, 2016). Only third $(31.0 \%)$ of respondents confirmed it has a clearly defined mission, however, merely two respondents were able to interpret it. Quality mission statement focuses on goals, points out core values and defines essential areas of competitiveness for the company in order to achieve competitive advantage (Vasiljev, et al., 2007). The lack thereof or vaguely formed mission statement impedes clear corporate goals and strategies from being defined, therefore hindering identification of marketing goals and strategy. It also contributes to non-objective overview of requirements, calculations and planning regarding the funding necessary for marketing which ultimately leads to complete absence of marketing activities.

In most of surveyed enterprises research is either not performed systematically or not performed at all. Marketing decisions are made subjectively by individuals, mainly on the basis of partial information or experience. Wang et.al (2016) asserts that executive's characteristics, predominantly age and formal education, significantly determine an organization's performance. Prior research (Hiebl, 2014) consistently indicated that younger executives and executives with business-related backgrounds are correlated with more innovative and/or sophisticated management systems. A decision made by a business entity should be made primarily on market research analysis related to the business entity and comparative advantage analysis (Palmatier and Sridhar 2017). According to cheesemakers' opinion, with the ability to grade quality of source of information with grade 1 to 5 and multiple choice answers, it was proven that the most significant source of information are distributors. Quality of information was ranked with an average grade of 3.6 (Table 3). Retail chains follow with an average grade of 3.5, information given by chambers of commerce (3.0), Statistical Office of the Republic of Serbia (2.9), internet (2.8) and the lowest grade belongs to the development agencies (2.6).

Table 3. Source and quality of information used by the marketing decision-makers

\begin{tabular}{|l|r|r|r|r|r|}
\hline \multicolumn{1}{|c|}{ Production Volume (tonne) } & Up to $\mathbf{9 9}$ & \multicolumn{1}{|c|}{$\begin{array}{c}\text { from } \mathbf{1 0 0} \\
\text { to } \mathbf{2 9 9}\end{array}$} & $\begin{array}{c}\text { from } \mathbf{3 0 0} \text { to } \\
\mathbf{5 9 9}\end{array}$ & $\begin{array}{c}\mathbf{6 0 0} \text { and } \\
\text { above }\end{array}$ & Total \\
\hline & \multicolumn{5}{|c|}{ Average grade } \\
\hline Chambers of commerce & 3.3 & 2.6 & 3.0 & 0.0 & 3.0 \\
\hline Development agencies & 2.9 & 2.0 & 0.0 & 0.0 & 2.6 \\
\hline Statistical Office of the Republic of Serbia & 1.8 & 4.3 & 3.0 & 3.0 & 2.9 \\
\hline Retail chains & 3.7 & 3.4 & 3.8 & 2.7 & 3.5 \\
\hline Distributors & 3.5 & 3.9 & 3.7 & 3.3 & 3.6 \\
\hline Internet & 2.0 & 5.0 & 4.0 & 0.0 & 2.8 \\
\hline
\end{tabular}

Source: Author's calculation based on the questionnaire data 
Competitive strategy of cheesemaking business affects the capacity to deliver value within entire dairy sector, additionally affecting economic efficiency of both processors and milk producers (Špicka, 2013). Consequently, an intensified vertical integration within dairy sector is needed, specifically between milk producers and processors. Apart from aforementioned advantages, vertical integration between cheesemakers and other participants of value chain creation and mutual horizontal link affect range and quality of total data necessary for marketing decision-making.

\section{Marketing Mix - Product}

Cow cheese predominates in the micro enterprises' assortments while only 1 of 18 manufacturers has sheep milk cheese in their assortment. Average number of different cheese in individual manufacturers' assortment is 3.6. Small enterprises have wider range of products in comparison to micro enterprises with an average number of 4.2 types of cheese in the individual manufacturers' assortment. There are cow, goat and sheep milk cheeses including semi-hard and processed cheeses. Medium-sized enterprises offer 5.8 varieties of cheese on average. In relation to small enterprises, expanded varieties of cow milk cheese can be noted such as soft cheese (equivalent to feta) and various semi-hard cheeses. There is also one manufacturer within this classification who produces goat milk cheese with certified organic product label (Table 4).

Table 4. Predominant product range of cheese from MSME

\begin{tabular}{|c|l|c|}
\hline $\begin{array}{c}\text { Company } \\
\text { size }\end{array}$ & \multicolumn{1}{|c|}{ Predominant product range } & $\begin{array}{c}\text { Average number } \\
\text { of cheese in } \\
\text { assortment }\end{array}$ \\
\hline Micro & $\begin{array}{l}\text { Fresh cow cheese milk (equivalent to cottage), plain ripe cheese and } \\
\text { ripe cheese with chilli pepper, soft low-fat cheese, semi-hard cow and } \\
\text { sheep milk cheese (equivalent to kashkaval), stretched curd cheese, } \\
\text { pizza cheese (equivalent to processed mozzarella), etc. }\end{array}$ & 3.6 \\
\hline Small & $\begin{array}{l}\text { Fresh cow cheese milk (equivalent to cottage), cream cheese, cheese } \\
\text { spread (variety of cream cheese), albumin cheese (equivalent to urdă); } \\
\text { plain fresh cheese, plain ripe cheese and fresh cheese with chilli } \\
\text { pepper (equivalent to feta); processed cheese (equivalent to edam), } \\
\text { varieties equivalent to trappist, kashkaval, mozzarella, pizza cheese; } \\
\text { goat milk cheese (fresh and ripe), goat milk cheese with dill, semi- } \\
\text { hard cheese, pizza cheese; mixed soft ripened sheep milk cheese, } \\
\text { fresh cheese (equivalent to feta). }\end{array}$ & 4.2 \\
\hline Medium- \\
sized & $\begin{array}{l}\text { Fresh cow cheese milk (equivalent to cottage), plain cream cheese } \\
\text { and cream cheese with chilli pepper, cheese spread (variety of cream } \\
\text { cheese), cream cheese, plain fresh cheese and plain ripe white cheese } \\
\text { (equivalent to feta), varieties equivalent to feta, kashkaval, gouda, } \\
\text { trappist, edam, organic fresh goat milk cheese, etc. }\end{array}$ & \\
\hline
\end{tabular}

Source: Author's calculation based on the questionnaire data

By gaining insight into product range of studied legal entities, it is noted that foundation consists of plain fresh cheese (equivalent to feta and ricotta), fresh cow cheese milk (equivalent to cottage), cream cheese and semi-hard cheese equivalent to kashkaval. Unlike numerous imported cheeses with herbs and spices, domestic manufacturers 
have modest product line regarding this type of cheese which is mostly limited to added paprika and dill. Starting point for creating product offer is market research of consumer needs and wants. Consumers usually see products as complex groups or benefits which meet their needs. For product development, marketing experts must first identify consumer's basic needs that the product should meet, then create the potential product and, ultimately, find a way to broaden it in order to create a set of benefits which will be of best use to the consumers (Kotler et al., 2007).

Considering the growing demand for organic products worldwide, one of the alternative directions for product development is the production of organic cheese. The steady increase in demand for organic products worldwide indicates that this production method can be very profitable if natural resources, knowledge and production experience are used properly (Hamzaoui-Essoussi \& Zahaf, 2012). One of the significant factors in the development of organic cheese production is certainly the education of producers, the level of support of local and regional agencies, development funds, as well as the strategic commitment of the state towards encouraging the production and export of high quality organic cheese. One more way to add cheese value, as a final product of milk processing, is to introduce and certify a food safety and quality system. All the companies that are the subject of this research have the HACCP standard, and most of them are in the ISO group.

Cheese production requires innovative technological solutions. Relatively uniform assortment, dominated by feta cow cheese, semi-hard cheese (equivalent to kashkaval), pizza cheese and fresh cow cheese milk (equivalent to cottage), indicate the possibilities of enhancing this strategic activity of the company, introducing cheeses according to the needs and demands of specific market segments such as children, athletes, then smaller packages with two or more types of cheese, with different additives, for use on various opportunities etc. The starting point of achieving long-term market affirmation in the domestic and export markets is the uniformity of the cheese quality and its standardization in accordance with the requirements of the market to which it is delivered. Increasingly, the modern consumer is shifting demand towards "healthy" products, which has led to the development of cheeses with improved nutritional properties, including cheeses with lower fat content, enriched with fatty acids, etc. (Jerónimo, et al., 2013). The existing range of cheese from the offer of domestic producers leaves the possibility of its expansion cheeses with longer ripening, lines of low-fat cheeses, various packages for parties, for children, portions provided for one meal, etc. Starting from the use, the important attribute is the shape and size of the cheese. Among the attributes related to cheese making, such as length and width of pieces, surface fineness, etc., U.S. consumers, for example, prefer longer, thicker, and truer pieces (Rankin, et al., 2006). Some of the attributes of cheese that consumers consider to be crucial when choosing cheese are its use, degree ofmaturity, ecopackaging, transparency, packaging convenience and safety, handmade cheese, degree of innovation,higher price, etc, (Užar,et.al, 2019). The packaging desing are of utmost importance in marketing communications. Form, material of production, graphic solutions, etc., influence the differentiation of cheese among competing products and 
enhances the image of the brand and the manufacturer. Creation of cheese packaging requires a methodical approach, respecting the requirements of environmental protection, international markets, distribution, etc. Packaging represents the last level of communication between the company and the consumer before making a purchasing decision, emphasizing its role in marketing communications (Rundh, 2013). Domestic producers, especially cow cheese, among micro, small and medium-sized enterprises pay insufficient attention to packaging. It is a common practice that packaging, instead of attractive and original graphic solutions, contains a set of obscure and unrelated objects, as well as inadequate photographs. This is not the case with the small number of goat cheeses, which come in the market in different packaging, with significantly better functional and aesthetic solutions, which can be partly justified by their higher selling price which leaves more space to cover the cost of packaging. The perceived values presented are important when selecting cheese, whereas effective positioning requires continuous communication with target segments, as well as conducting motivational and in-depth consumer research (Užar, et.al, 2019).

\section{Marketing Mix - Price}

According to studied business entities, price of the product has the greatest influence on buyers and consumers when it comes to making a purchase decision, i.e. $43.6 \%$ of respondents gave this factor the highest grade habits $(28.2 \%)$ are second, followed by packaging $(10.3 \%)$, brand $(7.7 \%)$, brand awareness, promotion $(5.1 \%)$ and availability in distribution channels $(5.1 \%)$. When it comes to information on declaration manufacturers claim that they do not affect purchase decision whatsoever. Expectedly, the represented hierarchy consisting of most important factors indicated that manufacturers notice the buyers' price orientation which is characteristic of low-income market such as the market of the Republic of Serbia. What comes as unexpected is the highly ranked response regarding habits which precede packaging, brand, etc. Such type of perception which, in addition, entrenches the attitude towards marketing as a secondary business activity is a reflection of core unfamiliarity with marketing. Taking into consideration manufacturers' attitude, it can be concluded that market behaviour of manufacturers is a result of viewing the role of marketing as peripheral: if habits influence purchase decision and considering consumer behaviour predictability, making investments and putting effort in creating marketing strategy and performing marketing activities is not necessary since it would not affect sales volume. Marketing concept recognizes that in order to achieve objectives, an organization should incorporate better integrated marketing activity efficiency than its competitor which is directed toward determining and meeting wants and needs of target markets (Kotler and Keller, 2016). Great number of companies use cost orientation for pricing, however, a lot of them set prices based on product value perceived by buyers and consumers (Breidert, 2007). Companies that make profitable pricing decisions have a proactive approach to pricing with regards to impact of pricing decision on how the consumers will observe it and develop the perception of product value (Monroe, et al., 2001). 
Notwithstanding the various pricing decisions among industries, different markets and different buyers and consumers, there is a mutual agreement in reference to pricing strategies which can be divided into three categories: cost-based pricing, competitionbased pricing and value-based pricing, i.e. pricing based on the customer perceived value (Hinterhuber, 2008). Regarding price setting and multiple choice answers, manufacturers expressed their opinion on the basis of company's current business practice. Out of 56 responses in total, $42 \%$ sets price by adding price margin to total costs; $33 \%$ of respondents use competition price as a basis for setting their own prices, $16.1 \%$ set price in accordance with identified market segmentation and willingness to pay for the product(s) whereas $7.1 \%$ adapts to the distributors' suggested price.

Unlike other marketing mix elements which create costs, price generates revenue. Hence, companies put in effort to determine prices on a level that would allow for product differentiation (Kotler, 2012). Product price interacts with other marketing mix elements whose final goal is profit maximization or market share increase. Price can have strategic and tactical role within business entities (Middleton, et.al, 2009). In accordance with the abovementioned and within the context of response structure on how the respondents set prices (relatively low responses to "Pricing based on indicated willingness of specific market segmentation to pay for the product") indicates low degree of cheese differentiation, lack of segmentation, low use of price as a marketing mix tool with the aim to establish position, create image, highlight quality, etc. One of the deciding factors for product selection in low purchasing power markets is price. It makes marketing activities even more complex and requires putting greater emphasis on product benefits and relevant consumer satisfaction. In conditions mentioned above, marketing has a task to increase brand awareness for a product, to increase the probability of product to be chosen because of its identified advantages and to emphasize - not just the financial advantage ("cheaper", "more for less") but also the "emotional" advantages ("feels good", "appreciated", "classy, fancy", "always by your side” etc.) (Rice, 2010).

\section{Marketing Mix - Distribution}

Marketing channels are an important element in the value chain of cheese, since it is a food item, whose production requires the milk of proven quality, under controlled conditions and as soon as possible reach the processors, as well as deliver the cheese as a finished product, at minimal cost, to consumers at the right place and time, in the right quantities and at the right price. Consumer habits are essential determinants when deciding which marketing channel to choose (Radosavljević, 2014). Distribution is a set of activities which make product available to target segment of buyers and consumers. Distribution of agricultural products must be adapted to the changes in the market environment (Kuzman, et al., 2017). Marketing channels, often called distribution channels in textbooks, represent a link between production and consumption which moves goods from producer to the consumer by a set of coordinated actions (Renko, 2009). Working on the assumption that business entities use more than a few distribution channels simultaneously, the respondents had the option for multiple 
choice answers. Most predominant distribution channel are retail stores (24.1\%), followed by restaurants $(20.7 \%)$, wholesalers $(16.4 \%)$, personal store brands $(15.5 \%)$ and supermarkets (14.7\%). The least used distribution channel for cheese placement are convenience stores $(8.6 \%)$.

\section{Marketing Mix - Promotion}

With the aim to stimulate demand, largest number of respondents offer discounts on certain amount of bought cheese $(48.1 \%)$, discounts for increased sales of specific cheese $(27.8 \%)$ and limited-time offers for entire assortment of goods (14.8\%). However, some manufacturers $(7.4 \%)$ do not offer discounts because, according to their opinion, it does not affect cheese sale and only one company allows discount to selected market segment of buyers and consumers (1.9\%).

In modern business environment with fragmentation of mass consumption markets, information technology development, media fragmentation and differentiation business entities are required to integrate greater number of communication channels. Integrated marketing communications include identifying target audiences and shaping coordinated promotion program with the aim to achieve desired reaction of target buyers and consumers (Batra and Keller, 2016). With the rational analysis of all relevant, continuously collected data and information, the marketing experts by coordinated functioning of all available processing departments, get to know with the needs of consumers, primarily, by perceiving the impact of qualitative and specific stimulus on buyers' decisions whether to buy or not (Puškarić et al., 2016). Question on cheese promotion allowed for multiple choice answers. Largest number of answers indicated that main type of promotion is by creating events and experience, i.e. cheese tasting at the sales location (23.5\%) and sales boost by providing extra quantities $(23.5 \%)$. Direct marketing in the form of printed promotional material or online shopping is implemented by $19.1 \%$ manufacturers while $8.8 \%$ of respondents use different types of advertising with the aim to inform, persuade, remind and encourage. According to Fuchs (2018) Internet increases social media's power in advertising and as news media. Castells (2009) that a larger number of producers online as compared to the broadcast model can reach a larger audience. Cheese producers should pay more attention to the internet as a promotional medium and instead of static, website should be a dynamic place for visitors to return. Content should be available in at least one other world language, especially within the presentation of those entities that export cheese or plan to export. The function of the website is to provide visitors with quality information and at the same time to be a source of information about visitors, an instrument of image enhancement, as well as a potential place of sale. Low degree of vertical integration reflects a relatively low involvement of promotional activities performed in cooperation with different food related organizations $(8.8 \%)$ as well as travel organizations $(5.9 \%)$. In addition, $10.3 \%$ of respondents do not utilize any type of marketing communications. 


\section{Swot analysis -micro, small and medium-sized enterprises}

Strategic analysis of internal and external factors based on assessment of company's own advantages and weaknesses, competition analysis, stakeholders and business environment analysis enable database creation necessary for marketing decisionmaking. The starting point for the development of an appropriate marketing strategy is the SWOT analysis, which introduces the previously anticipated characteristics of the cheese market in the Republic of Serbia into the context of strengths and weaknesses as internal factors, or opportunities and threats as external factors affecting the market performance of the business entities. The current situation in the field of cheese production and delivery is characterized by the following facts:

Table 5. Swot analysis of cheesemaking business enterprises

\begin{tabular}{|c|c|}
\hline Strengths & Weaknesses \\
\hline $\begin{array}{l}\text {-Favorable geostrategic position; } \\
\text {-Preferential tariff rates (CEFTA), free trade } \\
\text { (R. Federation); } \\
\text {-Available production capacity; } \\
\text {-Production in accordance with the minimum } \\
\text { one (HACCP) standard; } \\
\text {-Production of organic cheeses; } \\
\text {-Protected geographical indication of origin. }\end{array}$ & $\begin{array}{l}\text {-Lack of marketing knowledge and skills; } \\
\text { - Absence of segmentation and differentiation; } \\
\text { - Weakness of cheese brand image; } \\
\text { - Unclear strategic direction; } \\
\text { - Non-innovative and narrow assortment; } \\
\text { - Insufficient financial resources; } \\
\text {-Lack of standards introduced to meet specific market } \\
\text { needs. } \\
\text { - Producers' lack of interest in acquiring the status of } \\
\text { the authorized use of geographical origin }\end{array}$ \\
\hline Opportunities & Threats \\
\hline $\begin{array}{l}\text {-Growing demand of cheeses with a protected } \\
\text { geographical indication; } \\
\text {-Growing demand for organic cheeses; } \\
\text {-Exports to the market of the Russian } \\
\text { Federation and other members of the Eurasian } \\
\text { Economic Union } \\
\text {-Export of sheep cheese to different markets, } \\
\text { according to the specific requirements of the } \\
\text { standard (Halal, Kosher, etc.). } \\
\text {-Proximity to the CEFTA market and cost- } \\
\text { benefit in exports }\end{array}$ & $\begin{array}{l}\text {-Lack of domestic raw materials; } \\
\text {-Large assortment of imported cheeses; } \\
\text { - Entry of new competitors into the CEFTA markets; } \\
\text {-High quality requirements in export markets } \\
\text {-Low purchasing power in the domestic market; } \\
\text { - The increasing strength of cheese retailers and private } \\
\text { label brands } \\
\text {-Absence of marketing information system at dairy } \\
\text { industry level }\end{array}$ \\
\hline
\end{tabular}

Source: Author's calculation

Placing and analyzing the interplay of elements of the SWOT matrix gives insight into the factors that are decisive in formulating a marketing strategy and goals, for the purpose of realizing the overall goal: improving cheese promotion and marketing. In conditions of growing presence of global cheese brands' which are imported into the Serbian market, the pressure on domestic brands is rising. Hence it is necessary to identify factors which shape consumer and buyers' preferences. Taking that into consideration, developing a methodology and integrated marketing data collection system on consumers (needs, wishes, complaints, etc.) is essential. That could enable adequate and timely marketing decision-making, more efficient marketing communication, better positioning and greater product differentiation. 
Although enterprises possess significant factors necessary for taking advantage of the opportunities, the presented matrix indicates the priority need to eliminate or minimize several key weaknesses: lack of marketing knowledge and skills, lack of marketing as a business function in the organizational structure of the company, market segmentation, differentiation of supply and creating the image of cheeses by applying integrated marketing communications.

The following section identifies problems that implicitly arise from the perceived attitudes and opinions of marketing decision-makers, and indicate the weaknesses as well as the levels of support needs in the field of marketing. When it comes to the challenges faced by micro, small and medium-sized enterprises, $17.9 \%$ of respondents consider the presence of vegetable fat-based products with the addition of milk protein, from which it can be concluded that consumers perceive such products as cheeses (although these are not), which have a significantly lower price (table 6). In order to differentiate cheese from the aforementioned substitute, it is necessary for producers to corporate for common goals: consumer information and education, with an emphasis on the incomparability of cheese and the aforementioned products, while strengthening the position of local cheeses in the awareness of consumers.

Table 6. Attitudes of micro, small and medium enterprises on the biggest challenges and possible solutions within marketing activities

\begin{tabular}{|c|c|c|}
\hline Problems of entities & $\begin{array}{c}\text { Number of } \\
\text { responses }\end{array}$ & Framework of required marketing activities \\
\hline $\begin{array}{c}\text { The presence of vegetable fat- } \\
\text { based products with the addition of } \\
\text { milk protein. }\end{array}$ & $17.9 \%$ & Cooperative affiliate propaganda, positioning \\
\hline $\begin{array}{c}\text { The gray economy in the cheese } \\
\text { market. }\end{array}$ & $10.3 \%$ & Positioning \\
\hline Insufficient payment system. & $7.7 \%$ & $\begin{array}{c}\text { Creating unique value, differentiation, } \\
\text { strengthening identity and image, positioning. }\end{array}$ \\
\hline $\begin{array}{c}\text { Imports of cheeses from European } \\
\text { Union countries. }\end{array}$ & $5.1 \%$ & $\begin{array}{c}\text { Defensive marketing strategies, differentiation - } \\
\text { emphasis on attribute "home-made", "fresh milk", } \\
\text { product range innovation }\end{array}$ \\
\hline $\begin{array}{c}\text { Insufficient business relationship } \\
\text { between subcontractors and } \\
\text { manufacturers. }\end{array}$ & $5.1 \%$ & $\begin{array}{c}\text { Creating stronger and long-lasting relationships } \\
\text { between participants, production of cheeses with } \\
\text { geographical origin, branding }\end{array}$ \\
\hline $\begin{array}{c}\text { Great competition and market } \\
\text { supply of cheese. }\end{array}$ & $5.1 \%$ & $\begin{array}{c}\text { Introduction of marketing concept in business } \\
\text { of entities, production of cheese with protected } \\
\text { geographical indication. }\end{array}$ \\
\hline Other & $30.8 \%$ & - \\
\hline Without answer & $17.9 \%$ & - \\
\hline
\end{tabular}

Source: Author's calculation

The main identified deficiencies, which significantly influence the market position of manufacturers, are in fact the result of their attitudes, which are:

- Independent decision-making by the owner or director of the company; 
- Insufficient strategic orientation, reflecting lack of vision and mission in the company and consequently inconsistency of goals;

- Annual level of marketing investment, in approximately one fifth of respondents does not exceed EUR 500 (in RSD equivalent), and over half of producers (56.4\%) spend up to EUR 2,000 annually for marketing purposes;

- Narrow range of cheeses; Very limited selection, delivery and transfer of value through customer segmentation, product and service development, positioning, distribution, etc ;

- Overrated strengths related to the image and recognizability of cheeses;

- Insufficient, functionally usable marketing research and insufficient amount of marketing information on the basis of which customer and consumer segmentation can be performed;

- Low level of promotional activities and marketing communications.

The problems presented require the implementation of the marketing concept in the business practice of cheesemaking entities. Remaining producer responses (28.2\%), such as uncontrolled imports of milk and milk powder, unregulated raw milk market in the Republic of Serbia, lack of export support, inability to realize loans for "Start up" companies, etc., although not directly subject of marketing activities, are elements of the environment that significantly affect the ability to realize the marketing concept.

\section{Conclusion}

Marketing strategy planning, creating and improving product to possess adequate quality for a defined, solvent market demand and incorporating marketing mix tools are imperative to cheesemakers but also to other agribusinesses which perform product placement in both domestic and international market.

Business entities present in the recently liberalized market of the Republic of Serbia are deprived of marketing management knowledge. According to the results presented it can be concluded that studied business entities do not, or in a very limited approach, use marketing mix instruments which are not interlaced and do not complement each other.

Independent decision-making of the owner or general manager, including the identification of marketing with sales can lead to a distorted interpretation of buyers' wants and needs, competition, business entity's technological process, etc. At the age of fast market changes and high competition, marketing represents a key success factor of a company, therefore it is essential that decision-makers develop external and internal marketing capacities including adequate marketing information system adjusted in accordance with business entity size and activities.

Marketing strategy planning and utilization of marketing mix instruments become 
paramount on the road to solidify in the market and increase market share with the aim to create and maintain competitive advantage including the conditions of numerous market challenges such as: presence of various foreign brands and domestic cheeses, low purchasing power, high food safety standards, demands and requirements of distributors and retailers, limited financial resources, etc. The conclusions derived and methodology applied in this study are thought to serve as efficient guidelines for future research related to market-oriented companies. Given that this study did not identify articles examining purchase behavior in real market scenarios with real market transactions in this region, future research should focus on understanding of consumers' attitudes and their buying motives.

\section{Conflict of interests}

The authors declare no conflict of interest.

\section{References}

1. Batra, R., \& Keller, K.L. (2016). Integrating marketing communications: New findings, new lessons, and new ideas. Journal of Marketing, 80(6), 122-145. doi: https://doi.org/10.1509/jm.15.0419

2. Breidert, C. (2007). Estimation of willingness-to-pay: Theory, measurement, application. Springer Science \& Business Media.

3. Burke, N., Zacharski, K.A., Southern, M., Hogan, P., Ryan, M.P., \& Adley, C.C. (2018). The Dairy Industry: Process, Monitoring, Standards, and Quality. In Descriptive Food Science. IntechOpen.

4. Castells, M. (2009). Communication Power. Oxford: Oxford University Press

5. Chron: What Percentage of Gross Revenue Should Be Used for Marketing \& Advertising? Retrieved from http://smallbusiness.chron.com/percentage-grossrevenue-should-used-marketing-advertising-55928.html (February 12, 2020).

6. Cicea, C., Subić, J., \& Pirlogea, C. (2010). Considerations regarding investments efficiency in agriculture. Economia Seria Management, 13(2), 321-331.

7. Erić, D., Beraha, I., Đuričin, S., Kecman, N., \& Jakšić, B. (2012). Financing of SMEs in Serbia. Institut ekonomskih nauka: Privredna komora Srbije, 44-57.

8. Ferrell, O.C., \& Hartline, M. (2012). Marketing strategy, text and cases. Nelson Education.

9. Fuchs, C. (2018). Propaganda 2.0: Herman and Chomsky's Propaganda Model in the Age of the Internet, Big Data and Social Media. The Propaganda Model Today: Filtering Perception and Awareness. London: University of Westminster Press.

10. Gagné, M. (2018). From strategy to action: transforming organizational goals into organizational behavior. International Journal of Management Reviews, 20, 83104. doi: https://doi.org/10.1111/ijmr.12159

11. Hamzaoui-Essoussi, L., \& Zahaf, M. (2012). Production and distribution of organic foods: Assessing the added values. Organic Farming and Food Production, 145. doi: https://doi.org/10.5772/52445 
12. Hiebl, M.R. (2014). Upper echelons theory in management accounting and control research. Journal of Management Control, 24(3), 223-240. doi: https:/doi. org/10.1007/s00187-013-0183-1

13. Hinterhuber, A. (2008). Customer value-based pricing strategies: why companies resist. Journal of Business Strategy. 29(4). doi: https://doi. org/10.1108/02756660810887079

14. Jerónimo, E., \& Malcata, F.X. (2013). Sensory characteristics of cheese. In Handbook of cheese in health: Production, nutrition and medical sciences, 75 103, Wageningen Academic Publishers.

15. Jones, R., Suoranta, M., \& Rowley, J. (2013). Entrepreneurial marketing: a comparative study. The Service Industries Journal, 33(7-8). doi: https://doi.org/10. 1080/02642069.2013.740470

16. Kaleka, A., \& Morgan, A.N. (2017). How Marketing Capabilities and Current Performance Drive Strategic Intentions in International Markets. Industrial Marketing Management, 78(3), 108-121. doi: http://dx.doi.org/10.1016/j. indmarman.2017.02.001

17. Kotler, P. (2012). Kotler on marketing. Simon and Schuster.

18. Kotler, P., \& Keller, K.L. (2007). A framework for marketing management. Pearson Education.

19. Kotler, P., \& Keller, K.L. (2016). Marketing management (15th global ed.). England: Pearson.

20. Kuzman, B., Prdić, N., \& Dobraš, Z. (2017). The importance of the wholesale markets for trade in agricultural products. Economics of Agriculture, 64(3), 1177 1190. doi: https://doi.org/10.5937/ekoPolj1703177K

21. Lakhanya, L. (2015). Key internal factors affecting the small, medium and micro enterprises (SMMEs) marketing strategies in rural South Africa, Problems and Perspectives in Management, LLC Consulting Publishing Company Business Perspectives, 13(2).

22. McDonald, M. (2016). Strategic marketing planning: theory and practice. In The marketing book, Routledge, 108-142.

23. Monroe, K., \& Cox, J. (2001). Pricing Practices that Endanger Profits, Marketing Management, 10(3).

24. Middleton, V., Fyall, A., Morgan, M., \& Ranchhod, A. (2009). Marketing In Travel And Tourism, 4th Edition, Routledge.

25. Mugoša, I. (2018). Applying Marketing Concepts to Improve Cheese Production and Placing on the Market in the Republic of Serbia, PhD Tesis, Faculty of Agriculture, University of Novi Sad.

26. Ožegović, L., \& Pavlović, N. (2012). Management of Small and Medium-Sized Enterprises - holder of economic development, School of Business, 1, 74-84. [in Serbian: Ožegović, L., Pavlović, N. (2012). Menadžment malih i srednjih preduzeća-Nosilac razvoja privrede].

27. Palmatier, R., \& Sridhar, S. (2017). Marketing strategy : based on first principles and data analytics, Macmillan International Higher Education, London, Palgrave. 
28. Pavlović, N. (2009). The impact of small entities on economic growth. Razvoj $i$ upravljanje, 2(3), 40-42. [in Serbian: Pavlović, N. (2009). Uticaj malih preduzeća na privredni rast].

29. Puškarić, A., Kuzman, B., \& Maksimović, B. (2016). Impact of promotional activities on the development of autochthonous food products market. Ekonomika, 62(4). doi: https://doi.org/10.22004/ag.econ.290328

30. Radosavljević, K. (2014). The strategy of marketing channel development in agribusiness of the Republic of Serbia, PhD Tesis, Faculty of Economics, University of Belgrade

31. Rankin, S., Chen, C.M., Sommer, D., \& Esposito, A. (2006). Mozzarella and Scamorza cheese. Handbook of Food Science, Technology, and Engineering, 4, 150-1.

32. Renko, N. (2009). Marketing Strategies, Naklada Ljevak, Zagreb.

33. Rice, C. (2010). Understanding customers, Routledge.

34. Rundh, B. (2013). Linking packaging to marketing: how packaging is influencing the marketing strategy. British Food Journal.

35. Subić, J., Cicea, C., \& Jeločnik, M. (2017). Methodology And Software Application For Creation Of Business Plan In Any Area Of Agricultural Production, Proceedings of the International Management Conference, 11(1), 887-897, Faculty of Management, Academy of Economic Studies, Bucharest, Romania.

36. Špička, J. (2013). The competitive environment in the dairy industry and its impact on the food industry. Agris on-line Papers in Economics and Informatics, 5(8), 89-102.

37. Užar, D., Mugoša, I., \& Radojević, V. (2019). Positioning of Private Label Cheese Brands in the Republic of Serbia. Contemporary Agriculture, 68(3-4), 80-87. doi: https://doi.org/10.2478/contagri-2019-0013

38. Vasiljev, S., Cvetković, Lj., Kancir, R., \& Pantelić, D. (2007). Marketing management, 2, University of Novi Sad, Faculty of Economics

39. Wang, G., Holmes, R.M., Jr., Oh, I.S., \& Zhu, W. (2016). Do CEOs matter to firm strategic actions and firm performance? A meta-analytic investigation based on upper echelons theory. Pers. Psychol, 69, 775-862. doi: https://doi.org/10.1111/ peps. 12140 